JURNAL SEKRETARIS \& ADMINISTRASI BISNIS

Jurnal homepage http /ljurnal asmtb ac id/inde $x \mathrm{php} / \mathrm{jsab}$

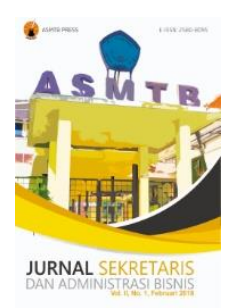

\title{
PENGARUH SATISFACTION TERHADAP ADVOCACY PADA MEREK LOKAL DENGAN LOYALTY SEBAGAI MEDIATOR (STUDI PADA THE EXECUTIVE)
}

Atika Ansary C. Mursalin ${ }^{1}$ dan Citra Kusuma Dewi²

1,2 Prodi Administrasi Bisnis, Fakultas Komunikasi dan Bisnis, Universitas Telkom

${ }^{1}$ atikaansarycm@student.telkomuniversity.ac.id, ${ }^{2}$ citrakusumadewi@telkomuniversity.ac.id

\section{ARTICLE INFO}

Article history:

Received $18^{\text {th }}$ January 2018

Received in revised form $02^{\text {th }}$ February 2018

Accepted $17^{\text {th }}$ February 2018

\section{Keywords:}

Satisfaction,

Loyalty,

Advocacy,

Fashion

\begin{abstract}
The purpose of this study is to determine the effect of Satisfaction toward advocacy on local brands with loyalty as mediator (study on the Executive). This research is a quantitative research with descriptive and causal data analysis, the respondents studied in this research are 100 consumers who have bought The Executive product. The data collected from 19 items of questionnaire statements were then diluted using IBM SPSS 24 with path analysis techniques. The results of this study indicate satisfaction is in position $74.71 \%$ with good category, loyalty is in the position of number $69.67 \%$ with good category, advocacy is at position number $72.35 \%$ with good category, significant satisfaction to loyalty 60,68 $\%$, loyalty have significant effect on advocacy equal to $21,43 \%$, satisfaction of advocacy equal to $13,76 \%$, and satisfaction of advocacy through loyalty equal to $36,10 \%$.
\end{abstract}

@ 2018 ASMTB PRESS

\section{Pendahuluan}

Di tengah maraknya pasar global, saat ini banyak pemasar dan perusahaan yang terhubung secara global dengan pelanggan dan mitra pemasar. Mudahnya pemasaran dalam era globalisasi akan mengakibatkan banyak produk global yang memasuki suatu negara dan mendorong konsumen untuk membeli produk tersebut (Paswan dan Sharma, 2004). Hal ini terlihat pada ajang tahunan yang diselenggarakan oleh Business Digest dan SWA yang menggelar ajang untuk mengapresiasi merekmerek asli karya putra-puteri negeri ini yang diberi tajuk Indonesia Original Brands (IOB). Dalam survei tersebut terdapat empat indikator penilaian seperti kepuasan (Satisfaction), loyalitas (Loyalty), advokasi (Advocacy), tingkat daya saing merek lokal terhadap merek asing (competitiveness).

Salah satu merek lokal yang mengalami penurunan IOB index adalah The Executive. The Executive adalah salah satu merek ternama Indonesia dalam bidang tren mode pakaian yang berdiri sejak tahun 1974. 


\section{PERKEMBANGAN IOB INDEX THE EXECUTIVE 2015-2017}

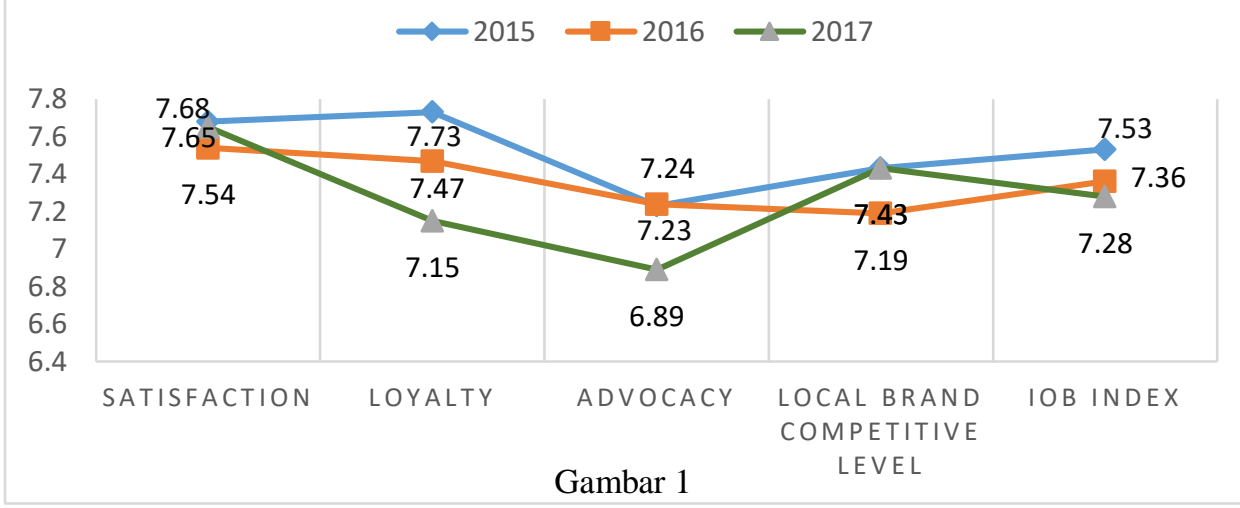

Perkembangan IOB Index The Executive 2015-2017

Pada gambar 1 terlihat empat indikator peniliain seperti satisfaction, loyalty, advocacy dan competitiveness mengalami penurunan yang cukup signifikan, sehingga berdampak juga pada penurunan indeks IOB. Nilai indeks IOB diperoleh dari jumlah rata-rata keempat indikator penilaian. Selain itu, survei ini menunjukan rendahnya indeks Advocacy di tahun 2017 yang menyentuh angka enam. Dalam hal ini yang perlu diperhatikan adalah bagaimana indeks advocacy lebih rendah dibandingkan indeks lainnya. Berdasarkan hasil survei pada the The Executive dapat diartikan untuk membuat pelanggan puas dan loyal adalah tugas yang berat. Dikutip dari SWA 2015, namun yang lebih berat lagi adalah membuat pelanggan advokat, yaitu pelanggan mau merekomendasikan kepada orang lain.

Seiring dengan perkembangan produk-produk The Executive, tentu akan memberikan dampak kepuasan terhadap konsumen pascapembelian. Menurut Kotler (2014:150) kepuasan adalah perasaan senang atau kecewa yang muncul setelah membandingkan kinerja (hasil) produk yang dipikirkan terhadap kinerja kerja (atau hasil) yang diharapkan. Dari definisi tersebut dapat dikatakan apabila produk The Executive tidak sesuai dengan harapan konsumennya dan bila harapan yang ditetapkan terlalu rendah, maka konsumen tersebut akan merasa tidak puas dan kecewa. Sehingga kemungkinan konsumen berpindah ke merek lain semakin besar, terutama merek pesaing yang dominannya adalah merek asing. Dalam hal ini kaitannya dengan hasil survei oleh Business Digest dan SWA, turunnya indeks advocacy bisa jadi merupakan efek berantai dari indeks satisfaction dan loyalty. Dikutip dari majalah SWA 2017, biasanya gradasi hubungan pelanggan terhadap merek pascapembelian/konsumsi akan bergerak dari satisfaction, loyalty dan yang tersulit adalah membangun advocacy.

Dikutip dari majalah SWA 2017, biasanya gradasi hubungan pelanggan terhadap merek pascapembelian/konsumsi akan bergerak dari satisfaction, loyalty dan yang tersulit adalah membangun advocacy. Meskipun terdapat empat indikator yang menjadi penilaian dalam indeks IOB, tetapi menurut Susanta, et al. (2013) pada teori relationship marketing yang paling utama yaitu satisfaction, loyalty dan advocacy. Hal ini diperkuat juga oleh Fiorella (2013) yang menyatakan bahwa yang menyatakan bahwa tahapan umum yang dihadapi oleh semua pemasar adalah Satisfaction, Loyalty dan Advocacy.

Berdasarkan uraian di atas yang menjalaskan mengenai pentingnya satisfaction, loyalty dan advocacy terutama bagi merek lokal, maka peneliti akan melakukan penelitian yang berjudul "Pengaruh Satisfaction terhadap Advocacy pada Merek Lokal dengan Costumer Loyalty sebagai Mediator (Studi pada The Executive)". 


\section{Kajian Literatur}

\section{Pemasaran}

Pemasaran adalah serangkaian aktivitas yang dilakukan perusahaan untuk menstimulasi permintaan atas produk yang dijual dan disampaikan kepada para pelanggan (Sudaryono, 2016:42). Mullins dan Walker (2013:5) mengemukakan bahwa pemasaran adalah sebuah proses sosial yang melibatkan kegiatan-kegiatan yang diperlukan untuk memungkinkan individu dan organisasi untuk mendapatkan apa yang mereka butuhkan dan inginkan melalui pertukaran terhadap yang lain dan untuk mengembangkan hubungan yang berkelanjutan.

\section{Relationship Marketing}

Customer relationship marketing menurut Winer (2013:13) adalah strategi untuk membangun hubungan yang baik dengan pelanggan dalam jangka panjang dengan mengkombinasikan kemampuan untuk merespon secara langsung dan untuk melayani pelanggan dengan interaksi yang tinggi. Selain itu, relationship marketing menurut Lee, Kim dan Pan (2014:1202) bertujuan untuk membangun hubungan satisfaction satu sama lain dengan para penyusun kunci agar dapat mempertahankan bisnis mereka. Relationship marketing bertujuan untuk membangun hubungan yang saling memuaskan dalam jangka panjang dengan konsumen, pemasok distributor dan lainnya (Priansa, 2017:6). Priansa (2017:6) menjelaskan bahwa ini penting untuk meningkatkan dan memelihara bisnisnya dalam jangka Panjang. Pengertian relationship marketing menurut Saputra dan Ariningsih (2014) merupakan sebuah konsep strategi pemasaran yang berupaya menjalin hubungan jangka panjang dengan para pelanggan, yaitu mempertahankan hubungan yang kokoh dan saling menguntungkan antara penyedia jasa dan pelanggan yang dapat membangun transaksi ulang dan menciptakan loyalty pelanggan. Menurut Fullerton (2011:92) pada era dimana relationship marketing merupakan fokus yang signifikan terhadap pemikiran dan praktik, penting untuk memiliki pemahaman yang lebih dalam menggerakan advocacy.

\section{Satisfaction}

Satisfaction menurut Kotler dan Keller (2016:153) adalah perasaan kecewa atau senang seseorang yang dihasilkan dari membandingkan kinerja atau hasil yang dirasakan terhadap produk atau layanan dengan harapan. Jika kinerja atau pengalaman tidak sesuai harapan, maka pelanggan tidak puas. Jika sesuai dengan harapan, maka pelanggan merasa puas. Jika melebihi ekspektasi, pelanggan sangat puas atau senang.

\section{Loyalty}

Menurut Priansa (2017:220), konsumen yang loyal merupakan aset penting bagi perusahaan, hal ini dapat dilihat dari karakteristik seperti melakukan pembelian secara teratur, membeli di luar lini produk/jasa, merekomendasikan produk, menunjukan kekebalan dari daya tarik produk sejenis dari pesaing. Priansa (2017:224) juga menjelaskan bahwa konsumen yang loyal akan kebal terhadap penawaran harga yang lebih menarik yang ditawarkan perusahaan asing.

\section{Advocacy}

Advocacy adalah keinginan pelanggan untuk memberikan rekomendasi yang kuat dan sikap memuji untuk pemasok produk atau jasa kepada konsumen lain (Susanta, et al, 2013:43). Menurut Lawer dan Knox (2006:5) tujuan dari Advocacy adalah untuk membangun hubungan yang lebih dalam kepada pelanggan baru dengan mengembangkan transparasi bersama, dialog, dan hubungan terhadap konsumen. Kotler dan Keller (2016: 171) menjelaskan bahwa meskipun memiliki pengaruh yang paling kuat pada situasi pilihan konsumen, faktor keputusan yang paling penting adalah "rekomendasi dari konsumen".

\section{Kerangka Pemikiran}

Berdasarkan uraian di atas, maka kerangka pemikiran penelitian sebagai berikut: 


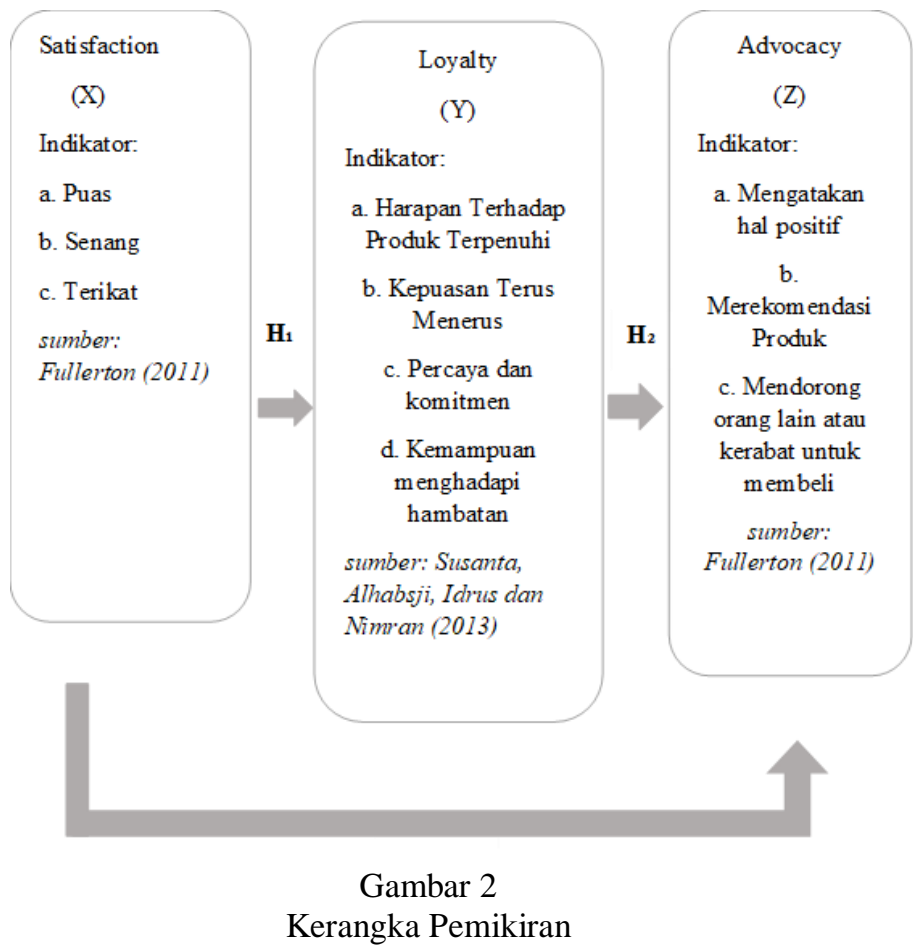

Metode Penelitian

\section{Jenis Penelitian}

Penelitian ini menggunakan jenis penelitian deskriptif-kausalitas dengan metode kuantitatif.

\section{Operasional Variabel dan Skala Pengukuran Operasional Variabel}

Terdapat tiga variabel penelitain yang digunakan dalam penelitian ini, yaitu variabel bebas Satisfaction (X), variabel mediator Loyalty (Y) dan variabel terikat Advocacy (Z).

\section{Skala Pengukuran}

Skala yang digunakan dalam desain pengukuran penelitian ini adalah skala likert. Skala likert digunakan untuk mengukur sikap, pendapat dan persepsi seseorang atau sekelompok orang tentang fenomena sosial (Sugiyono, 2017:93).

\section{Populasi dan Sampel}

Populasi

Pengertian populasi menurut Sugiyono (2017:80) adalah wilayah generalisasi yang terdiri atas obyek atau subyek yang mempunyai kualitas dan karakteristik tertentu yang ditetapkan oleh peneliti untuk dipelajari dan kemudian ditarik kesimpulannya. Dalam penelitian ini, populasi yang digunakan adalah pelanggan produk The Executive.

\section{Sampel dan Teknik Sampling}

Menurut Sugiyono (2017:81) sampel adalah bagian dari jumlah dan karakteristik yang dimiliki oleh populasi tersebut. Pengambilan sampel yang digunakan dalam penelitian ini adalah Non Probability Sampling karena jumlah dari pelanggan produk The Executive yang tidak memiliki data pasti. Sugiyono (2017:84) mendefinisikan Non-Probability sampling adalah Teknik pengambilan sampel yang tidak memberi peluang atau kesempatan sama bagi setiap unsur atau anggota populasi untuk dipilih menjadi sampe. Teknik pengambilan sampel dalam penelitian ini menggunakan sampling purposive. Sampling purposive adalah Teknik penentuan sampel dengan petimbangan tertentu (Sugiyono, 2017:85). Pertimbangan yang diambil dalam menentukan sampel adalah pelanggan yang pernah membeli merek lokal The Executive. Pada penelitian ini, mengingat jumlah populasi tidak diketahui maka dalam menentukan jumlah sampel menggunakan rumus Wibisono (2003) dalam Riduwan dan Kuncoro (2011:50) sebagai berikut: 
Keterangan:

$$
n=\left(\frac{(Z \alpha / 2)(\sigma)}{e}\right)^{2}
$$

$\mathrm{n}=$ ukuran sampel minimum

$\mathrm{Z}=$ Nilai distribusi normal baku (table Z) pada $\alpha$

$\sigma=$ Standar deviasi

$\mathrm{e}=$ erorr tolerance maksimum

Dalam penelitian ini digunakan batas toleransi kesalahan (error tolerance) dari pengambilan sampel adalah $5 \%$, yang berarti keputusan penelitian untuk menolak atau mendukung hipotesis nol memiliki probabilitas kesalahan sebesar 5\%. Tingkat kepercayaan yang digunakan adalah sebesar 95\% sehingga nilai $\mathrm{Z}(1,96)$. Untuk mengukur penelitian dengan menggunakan stanfar error kurang dari 0,05 dan standara deviasinya sebesar 0,25. Dengan memasukan ke dalam rumus diatas, sehingga diperoleh jumlah sampel minimal dalam penelitian ini adalah:

$\mathrm{n}=\left(\frac{(1,96)(0,25)}{0,05}\right)^{2}=96,04$ responden

Berdasarkan hasil hitung sampel, diperoleh angka 96,04 untuk jumlah sampel minimum, tetapi peneliti membulatkannya menjadi 100 responden pelanggan The Executive untuk mengurangi kesalahan pengisian kuesioner. Peneliti menggunakan sampel sebanyak 100 orang konsumen The Executive yang disebarkan melalui sosial media twitter, Instagram, dan Facebook kepada follower pada akun resmi The Executive dengan bantuan google form.

\section{Jenis Data dan Teknik Pengumpulan Data}

Jenis data yang diperlukan dalam penelitian ini adalah data primer dan data sekunder. Teknik pengumpulan data pada penelitian ini menggunakan kuesioner dan studi pustaka.

\section{Uji Validitas dan Reliabilitas}

Perhitungan uji validitas untuk kuesioner dilakukan menggunakan Pearson Product Moment sedangkan uji reliabilitas yang digunakan adalah dengan menggunakan Chronbach's Alpha. Kedua uji tersebut dilakukan dengan menggunakan Software SPSS versi 24 for Windows. Berdasarkan hasil uji validitas dan reliabilitas, instrumen dalam penelitian telah valid dan reliabel.

\section{Hasil dan Diskusi \\ Hasil}

Dari hasil penyebaran kuesioner yang diperoleh dari 100 responden sebanyak 72 orang atau $72 \%$ didominasi perempuan, untuk Kota tempat membeli The Executive didominasi di Kota Bandung sebanyak 38 orang atau 38\%, berdasarkan usia didominasi 18-25 tahun sebanyak 87 orang atau $87 \%$, berdasarkan Intensitas pembelian didominasi dengan melakukan pembelian beberapa kali dalam kurun waktu satu tahun sebanyak 36 orang atau 36\%, pekerjaan didominasi oleh Pelajar/Mahasiswa sebanyak 74 orang atau 74\%, pendapatan per bulan didominasi sebesar Rp 1.000.001 - Rp 3.000.000 sebanyak 43 orang atau $43 \%$.

\section{Uji Asumsi Klasik}

Pada penelitian ini digunakan dua uji asumsi klasik terhadap model regeresi yang telah diatur dengan menggunakan program SPSS. Uji asumsi klasik ini meliputi uji normalitas dan uji heterokedastisitas. Karena dalam penelitian ini menggunakan model analisis jalur, sehingga perhitungan dibagi kedalam dua uji sub-struktur, yaitu sub-struktur 1 untuk mengetahui variabel $X$ terhadap $Y$ dan sub-struktur 2 untuk mengetahui variabel X dan Y terhadap Z. Dari hasil uji asumsi klasik terhadap 100 responden bahwa data pada sub-struktur 1 dan sub-struktur 2 menunjukan data berdistrubusi normal dan tidak terdapat gejala heterokedastisitas, artinya data digunakan layak untuk diolah guna dilakukan uji perhitungan pada tahap selanjutnya. 


\section{Uji Sub-Struktur 1}

Berdasarkan hasil perhitungan menggunakan SPSS, maka diperoleh persamaan struktural untuk SubStruktur 1 diagram jalurnya seperti pada gambar 7 berikut:

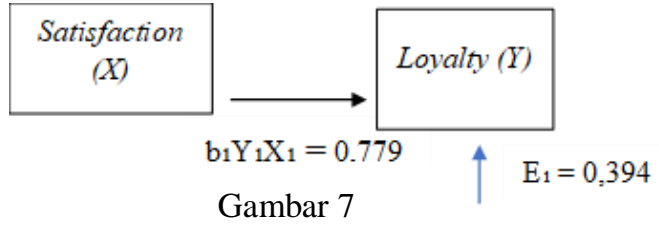

Hubungan kausal Sub-Struktur 1 pengaruh X terhadap Y

Dari pengujian tersebut, maka diperoleh persamaan Sub-Struktur 1 sebagai berikut:

$\mathrm{Y}_{1}=\mathrm{b}_{1} \mathrm{Y}_{1} \mathrm{X}_{1}+\mathrm{E}_{1}$

$Y_{1}=0,779+0,394$

\section{Uji Sub-Struktur 2}

Berdasarkan hasil perhitungan menggunakan SPSS, maka diperoleh persamaan struktural SubStruktur 2 diagram jalur seperti pada gambar 8 dan 9sebagai berikut:

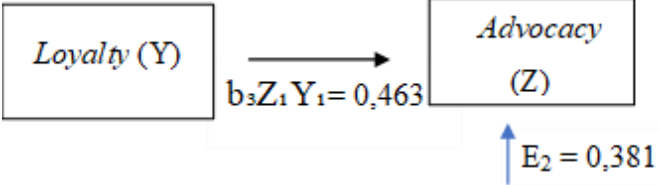

Gambar 8

Hubungan kausal Sub-Struktur 2 pengaruh Y terhadap Z

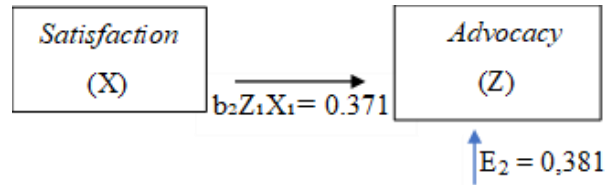

Gambar 9

Hubungan kausal Sub-Struktur 2 pengaruh X terhadap Z

Dari pengujian tersebut, maka diperoleh persamaan Sub-Struktur 2 sebagai berikut:

$\mathrm{Z}_{1}=\mathrm{b}_{2} \mathrm{Z}_{1} \mathrm{X}_{1}+\mathrm{b}_{3} \mathrm{Z}_{1} \mathrm{Y}_{1}+\mathrm{E}_{2}$

$Z_{1}=0,371+0,463+0,381$

\section{Model Analisis Jalur}

Berdasarkan hasil dari koefisien jalur pada Sub-Struktur 1 dan Sub-Struktur 2, maka dapat digambarkan secara keseluruhan yang menggambarkan hubungan kausal antar variabel $\mathrm{X}$ dan $\mathrm{Y}$ terhadap Z sebagai berikut:

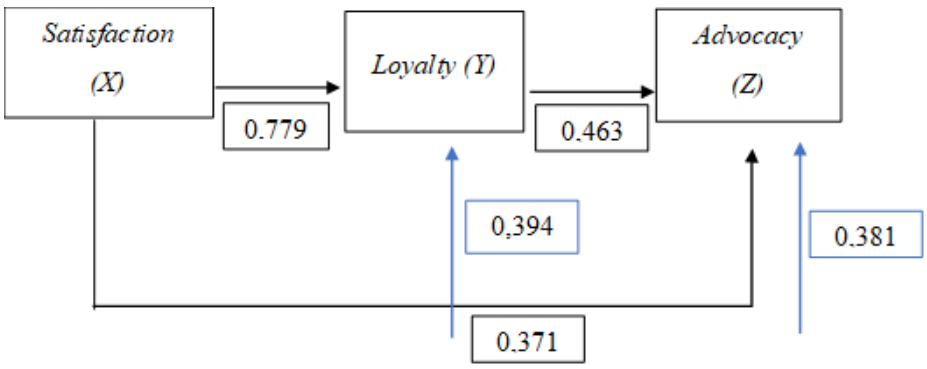

Gambar 10

Hasil Model Analisis Jalur 


\section{Merangkum Koefisien Jalur}

Berikut adalah tabel 1 yang merupakan rangkuman koefisien jalur.

\begin{tabular}{|c|c|c|c|c|c|}
\hline \multirow{2}{*}{ Variabel } & \multirow{2}{*}{$\begin{array}{c}\text { Koefisien } \\
\text { Jalur }\end{array}$} & Langsung & $\begin{array}{c}\text { Tidak } \\
\text { Langsung }\end{array}$ & $\begin{array}{c}\text { Total } \\
(\%)\end{array}$ & Keterangan \\
\cline { 4 - 6 } & & & & & \\
\hline X terhadap Y & 0,779 & 0,6068 & - & 60,68 & Signifikan \\
\hline Y terhadap Z & 0,463 & 0,2143 & - & 21,43 & Signifikan \\
\hline X terhadap Z & 0,371 & - & - & 13,76 & Signifikan \\
\hline X terhadap Z melalui Y & 0,361 & - & 0,361 & 36,10 & Signifikan \\
\hline
\end{tabular}

Tabel 1

Sumber: Data diolah peneliti (2017)

Pengaruh Langsung dan Tidak Langsung

Hasil keseluruhan pengaruh antar variabel dijelaskan sebagai berikut:

a. Pengaruh langsung antara satisfaction (X) terhadap loyalty (Y) sebesar 60,68\% dan sisanya $39,32 \%$ dipengaruhi oleh variabel lain di luar penelitian ini.

b. Pengaruh langsung antara loyalty (Y) terhadap advocacy $(\mathrm{Z})$ sebesar $21,43 \%$ dan sisanya $78,59 \%$ dipengaruhi oleh variabel lain di luar penelitian ini.

c. Pengaruh langsung antara satisfaction (X) terhadap Advocacy (Z) sebesar 13,76\% dan sisanya $86,24 \%$ dipengaruhi oleh variabel lain di luar penelitian ini.

d. Pengaruh tidak langsung antara satisfaction (X) terhadap advocacy $(\mathrm{Z})$ melalui loyalty $(\mathrm{Y})$ sebesar $36,1 \%$ dan sisanya $63,9 \%$ dipengaruhi oleh variabel lain di luar penelitian ini. Nilai signifikan pada pengaruh ini diperoleh dari hasil perkalian Sig. hubungan X terhadap Y dengan hubungan $Y$ terhadap $Z$ yaitu $0,000 \times 0,00=0,000<$ nilai $\alpha=0,05$.

\section{Uji Hipotesis}

Pengujian secara Parsial (Individual) dengan T-test

a. Hubungan Struktur X terhadap Y

Nilai probabilitas $(\mathrm{Sig})=0,000$ nilai $<\alpha=0,05$, maka keputusannya adalah $\mathrm{H}_{0}$ ditolak dan $\mathrm{H}_{a}$ diterima artinya bahwa Satisfaction (X) berpengaruh terhadap Loyalty (Y). Dengan demikian hipotesis pertama $\left(\mathrm{H}_{1}\right)$ yang diajukan peneliti diterima, artinya bahwa Satisfaction berpengaruh secara signifikan terhadap Loyalty.

b. Hubungan terhadap Struktur Y terhadap Z

Nilai probabilitas $(\mathrm{Sig})=0,000<$ nilai $\alpha=0,05$, maka keputusannya adalah $\mathrm{H}_{0}$ ditolak dan $\mathrm{H}_{\mathrm{a}}$ diterima artinya bahwa Loyalty (Y) berpengaruh terhadap Advocacy (Z). Dengan demikian hipotesis kedua $\left(\mathrm{H}_{2}\right)$ yang diajukan peneliti diterima, artinya bahwa Loyalty berpengaruh secara signifikan terhadap Advocacy.

c. Hubungan Struktur X terhadap Z.

Nilai probabilitas $(\mathrm{Sig})=0,000<$ nilai $\alpha=0$, 05, maka keputusan adalah $\mathrm{H}_{0}$ ditolak dan $\mathrm{H}_{a}$ diterima artinya bahwa Satisfaction (X) berpengaruh terhadap Advocacy (Z). Dengan demikian hipotesis ketiga $\left(\mathrm{H}_{3}\right)$ yang diajukan peneliti diterima, artinya bahwa Satisfaction berpengaruh secara signifikan terhadap Advocacy.

d. Hubungan Struktur X terhadap Z melalui Y.

Nilai probabilitas (Sig) ini diperoleh dari hasil perkalian Sig. hubungan X terhadap Y dengan hubungan $\mathrm{Y}$ terhadap $\mathrm{Z}$ yaitu $0,000 \times 0,00=0,000<$ nilai $\alpha=0,05$, maka keputusan adalah $\mathrm{H}_{0}$ ditolak dan $\mathrm{H}_{\mathrm{a}}$ diterima artinya bahwa Satisfaction $(\mathrm{X})$ berpengaruh terhadap Advocacy $(\mathrm{Z})$ 
melalui Loyalty (Y). Dengan demikian hipotesis keempat $\left(\mathrm{H}_{4}\right)$ yang diajukan peneliti diterima, artinya bahwa Satisfaction berpengaruh secara signifikan terhadap Advocacy melalui Loyalty.

\section{Diskusi}

Analisis dapat dilakukan setelah menyebarkan kuesioner yang terdiri 19 item pernyataan kepada 100 responden konsumen yang pernah menggunakan merek lokal The Executive. Hasil penelitian ini menggunakan software IBM (SPSS) Statistis versi 24 for Windows. Hasil analisis kausal bertujuan menguji apakah terdapat pengaruh antar Satisfaction, Loyalty dan Advocacy yang dijelaskan sebagai berikut:

\section{Satisfaction konsumen pada merek lokal The Executive}

Pembahasan variabel Satisfaction (X) pada konsumen The Executive didasarkan pada teori Satisfaction adalah perasaan kecewa atau senang seseorang yang dihasilkan dari membandingkan kinerja atau hasil yang dirasakan terhadap produk atau layanan. Pelanggan akan merasa puas jika produk atau layanan sesuai dengan harapan (Kotler dan Keller, 2016:153). Satisfaction terdiri dari tiga indikator yaitu perasaan puas, senang dan terikat (Fullerton, 2011:97)

Berdasarkan hasil penelitian analisis deskriptif, menunjukan bahwa tanggapan responden terhadap variabel satisfaction secara keseluruhan termasuk dalam kategori baik, hal ini terlihat dari persentase rata-rata total sebesar $74,71 \%$. Hal ini menunjukan baik harga, kualitas, dan jenis produk dari The Executive telah memenuhi kepuasan konsumen pasca pembelian. Namun tingkat puas dan senang dari konsumen terhadap harga masih rendah yang juga menyebabkan keterikatan konsumen terhadap produk The Executive ikut rendah. Lebih lanjut terlihat pada item-item yang terkait harga di indikator puas dan senang y. Item-item ini menunjukan nilai yang paling rendah pada masing-masing indikator dan termasuk dalam kategori cukup baik.

\section{Loyalty konsumen pada merek lokal The Executive}

Pembahasan variabel Loyalty (Y) pada konsumen The Executive didasarkan pada teori loyalty sebagai sikap positif konsumen terhadap suatu merek dan konsumen memiliki keinginan kuat untuk membeli ulang produk yang sama pada saat sekarang dan masa yang akan datang (Sudaryono, 2014:49). Terdapat empat indikator yang digunakan dalam mengukur loyalty menurut Susanta et al. (2013:43), yaitu harapan terhadap produk terpenuhi, kepuasan terus menerus terhadap produk, percaya dan komitmen untuk membeli produk itu lagi, dan kemampuan menghadapi hambatan.

Berdasarkan hasil penelitian analisis deskriptif menunjukan bahwa tanggapan responden terhadap variabel Loyalty secara keseluruhan termasuk dalam kategori baik, hal ini terlihat dari persentase ratarata total sebesar 69,67\%. Hal ini menunjukan bahwa kebanyakan responden merasa loyal setelah membeli produk The Executive. Sama halnya dengan item pada satisfaction, item loyalty yang terkait harga juga memiliki persentase yang rendah. Tingkat kemampuan konsumen dalam menghadapi hambatan kenaikan harga produk The Executive masih rendah, terlihat pada nilai persentase sebesar $62,60 \%$ yang termasuk dalam kategori cukup baik. Hal ini merupakan dampak dari rendahnya nilainilai item yang terkait harga pada variabel satisfaction. Selain itu juga dapat disebabkan oleh karakteristik responden yang lebih didominasi oleh Pelajar/Mahasiswa yang biasanya belum memiliki penghasilan tetap.

\section{Advocacy konsumen pada merek lokal The Executive}

Pembahasan variabel Advocacy (Z) pada konsumen The Executive didasarkan pada teori Advocacy, yaitu keinginan pelanggan untuk memberikan rekomendasi yang kuat dan sikap memuji terhadap produk atau jasa kepada konsumen lain (Susanta et al., 2013:43). Terdapat tiga indikator untuk mengukur variabel advocacy yaitu mengatakan hal positif kepada orang lain tentang produk, merekomendasikan produk kepada orang lain yang membutuhkan informasi, mendorong temanteman dan kerabat untuk membeli produk. 
Berdasarkan hasil penelitian deskriptif menunjukan bahwa tanggapan responden terhadap variabel Advocacy secara keseluruhan termasuk dalam kategori baik, hal ini terlihat dari persentase rata-rata total sebesar $72.35 \%$. Hal ini menunjukan kebanyakan responden memberikan rekomendasi yang kuat dan memuji terhadap produk The Executive kepada orang lain. Namun terdapat satu item yang memiliki persentase paling rendah, yaitu item terkait pembelaan terhadap isu negative dari produk The Executive. Item ini termasuk dalam kategori cukup baik sebesar $66 \%$. Isu negative yang menjadi perhatian, bisa saja terkait dengan harga mengingat rendahnya nilai persentase pada dua item pada variabel satisfaction dan satu item pada variabel loyalty. Selain itu faktor karakteristik responden yang lebih didominasi oleh Pelajar/Mahasiswa yang biasanya belum memiliki penghasilan tetap.

\section{Pengaruh satisfaction terhadap Loyalty konsumen merek lokal The Executive}

Penelitian ini bertujuan untuk menjawab hipotesis pertama $\left(\mathrm{H}_{1}\right)$ yang diajukan yaitu mengetahui pengaruh Satisfaction (X) terhadap Loyalty (Y) konsumen merek lokal The Executive. Pada model sub-struktur 1 diketahui besarnya pengaruh Satisfaction terhadap Loyalty sebesar $60,68 \%$. Hasil ini sesuai dengan penelitian yang dilakukan oleh Susanta et al. (2013) dimana terdapat pengaruh positif dan signifikan antara variabel satisfaction terhadap variabel loyalty sebesar $0,262, \mathrm{P}<0,05$ namun dengan objek yang berbeda.

Hal ini menunjukan bahwa konsumen yang merasa puas dengan produk The Executive dapat mempengeruhi sikap loyal terhadap produk ini. Hasil ini didukung juga dengan teori yang dikemukakan oleh Sudaryono (2014:49), yang menjelaskan bahwa satisfaction akan mendorong konsumen untuk mengulang perilaku pembelian. Lebih lanjut diuraikan bahwa loyalty sangat tergantung dengan satisfaction konsumen, semakin puas seorang konsumen terhadap suatu merek, semakin loyal konsumen tersebut terhadap suatu merek (Sudaryono, 2014:52).

\section{Pengaruh loyalty terhadap advocacy konsumen merek lokal The Executive}

Penelitian ini bertujuan untuk menjawab hipotesis kedua $\left(\mathrm{H}_{2}\right)$ yang diajukan yaitu mengetahui pengaruh Loyalty (Y) terhadap Advocacy (Z) konsumen merek lokal The Executive. Pada model substruktur 2 diketahui bahwa pengaruh Loyalty terhadap Advocacy sebesar 21, 43\%. Hasil ini sesuai dengan penelitian yang dilakukan oleh Susanta et al. (2013) dimana terdapat pengaruh positif dan signifikan antara variabel loyalty terhadap variabel advocacy sebesar $0,271, \mathrm{p}<0,05$, namun dengan objek yang berbeda.

Hal ini menunjukan bahwa konsumen yang loyal terhadap produk The Executive akan memicu dalam melakukan advokasi. Hasil ini didukung juga dengan teori yang dikemukan oleh Priansa (2017:220) yang menjelaskan bahwa salah satu karakteristik konsumen yang loyal akan merekomendasikan produk terhadap konsumen lain. Menurut Susanta et al. (2013:46), untuk menjadi konsumen yang memiliki sikap advocacy konsumen tersebut harus benar-benar loyal terhadap produk.

\section{Pengaruh satisfaction terhadap advocacy konsumen merek lokal The Executive}

Penelitian ini bertujuan untuk menjawab hipotesis ketiga $\left(\mathrm{H}_{3}\right)$ yang diajukan yaitu mengetahui pengaruh langsung Satisfaction (X) terhadap Advocacy (Z) konsumen merek lokal The Executive. Pada model sub-struktur 2 diketahui bahwa pengaruh Satisfaction terhadap Advocacy sebesar 13,76\% dan memiliki pengaruh positif dan signifikan karena nilai $\mathrm{F}$ hitung 78,855 $>\mathrm{F}$ table 2,31 dan sig. $=$ $0,00<$ nilai $\alpha=0,05$. Hasil ini sesuai dengan penelitian yang dilakukan oleh Fullerton (2011) dimana terdapat pengaruh positif dan signifikan antara variabel loyalty terhadap variabel advocacy.

Hal ini menunjukan bahwa konsumen yang puas terhadap produk The Executive akan memicu dalam melakukan advokasi. Hasil ini didukung dengan teori yang dikemukakan oleh Kotler dan Keller (2016:200), bahwa konsumen yang puas cenderung untuk mengatakan hal yang baik tentang merek tersebut. Sedangkan menurut Howard dan Kerin (2013:367) mengemukakan bahwa Satisfaction 
berhubungan positif dengan advocacy dan keterikatan afektif terhadap merek yang didasari kemauan untuk melakukan advocacy terhadap merek-merek tersebut.

\section{Pengaruh satisfaction terhadap advocacy konsumen merek lokal dengan loyalty sebagai mediator}

Penelitian ini bertujuan untuk menjawab hipotesis keempat $\left(\mathrm{H}_{4}\right)$ yang diajukan yaitu mengetahui pengaruh Satisfaction (X) terhadap Advocacy (Z) konsumen merek lokal The Executive dengan Loyalty (Y) sebagai mediator. Besarnya pengaruh tidak langsung antara variabel satisfaction terhadap advocacy melalui loyalty yaitu sebesar $36,10 \%$. Nilai ini lebih besar dibanding pengaruh langsung satisfaction terhadap advocacy. Hal ini didukung dengan hasil survey yang dilakukan oleh Business Digest Majalah SWA yang menyatakan bahwa gradasi hubungan pelanggan terhadap merek pasca pembelian akan bergerak dari satisfaction, loyalty dan yang tersulit adalah membangun advocacy. Artinya loyalty memiliki peran penting dalam melakukan kegiatan advocacy pada The Executive.

\section{SIMPULAN}

Jadi dalam penelitian ini menunjukan bahwa setelah konsumen merasa puas (Satisfaction) kemudian merasa loyal (Loyalty), maka akan melakukan advocacy yang lebih besar dibandingkan konsumen yang hanya merasa puas saja. Dalam hal ini perusahaan perlu lebih fokus untuk mampu membangun Loyalty yang lebih baik. Namun dari hasil analisis deskriptif menunjukan Loyalty memiliki nilai persentase terkecil dibandingkan dengan variabel lain. Melihat nilai item yang rendah pada variabel Satisfaction dan Loyalty adalah mengenai harga, maka The Executive perlu melakukan strategi dalam melakukan penetapan harga. Beberapa taktik penawaran harga yang dapat dilakukan seperti memberikan penawaran khusus "buy one get one", dan mengadakan kartu membership kemudian memberikan potongan harga yang lebih besar bagi konsumen yang menjadi member The Executive. Selain itu, meninjau dari cara memperoleh data responden adalah melalui media sosial sehingga karakteristik responden yang didominasi adalah remaja muda yang aktif menggunakan internet, sebagai tambahan The Executive perlu memanfaatkan akun resmi pada sosial media sebagai wadah untuk mempromosikan penawaran harga.

Dalam penelitian ini diharapkan dengan adanya peran Loyalty maka advocacy pada The Executive dapat meningkat lebih baik. Meskipun terdapat pengaruh langsung Satisfcation terhadap Advocacy, tetapi yang terpenting adalah kita tidak bisa mengenyampingkan adanya Loyalty sebagai mediator.

\section{Daftar Pustaka}

Horward, D., \& Kerin, R. (2013). A Surname Brand Effect Explanation for Consumer Brand Preference and Advocacy. Journal of Product \& Brand Management Vol. 22 No.5/6, 362-370.

Fiorella, S. (2013). Customer Loyalty and Advocacy are Not Interchangeable Concept . Retrieved from Sensei Marketing: https://senseimarketing.com/customer-loyalty-and-advocacy-are-notinterchangeable-concepts/.

Fullerton, G. (2011). Creating advocates: The roles of satisfaction, trust and commitment. Journal of Retailing and Consumer Services, 92-100.

Kotler, P., Keller, \& Lane, K. (2013). Manajemen Pemasaran, Jilid 2, Edisi 13. Erlangga.

Kotler, P., \& Keller, K. L. (2016). Marketing Management Review, Student Value Edition (15th Edition). 
Lawer, C., \& Knox, S. (2006). Customer Advocacy and Brand Management. Journal of Product \& Brand Management, Volume 15, Issue 2,, 121-129.

Mullins, J. W., \& Walker, O. C. (2013). Marketing Management: A Strategic Decision - Making Approach. McGraw-Hill.

Paswan, A. K., \& Sharma, D. (2004). Brand-country of origin (COO) knowledge and COO image: investigation in an emerging franchise market. Journal of Product and Brand Management Vol. 13 Issue: 3, 144-155.

Priansa, D. J. (2017). Perilaku Konsumen dalam Persaingan Bisnis Kontemporer. Bandung: Alfabeta.

Riduwan, \& Kuncoro, A. E. (2011). Cara Menggunakan dan Memakai Path Analysis (Anlisis Jalur). Bandung: Alfabeta.

Rivai, V., \& Sagala, E. (2013). Manajemen Sumber Daya Manusia Untuk Perusahaan. Edisi Kedua. Jakarta: PT Rajagrafindo Persada .

Saputra, \& Ariningsih. (2014). Masa Depan Penerapan Strategi Relationship Marketing. Jurnal Manajemen dan Bisnis Volume 10 No 1.

Sudaryono, D. (2016). Manajemen Pemasaran Teori dan Implementasi. Yogyakarta: C.V Andi Offset.

Sugiyono. (2017). Metode Penelitian Kuantitatif, Kualitatif dan R\&D. Bandung: CV Alfabeta

Suryadi, D. (2015, Juli 27). Merek-Merek Unggulan Asli Indonesia. SWA: TOP 250 INDONESIA ORIGINAL BRANDS 2015, pp. 44-54.

Suryadi, D. (2016, Mei 26). Merek-Merek Lokal Digdaya Di Negeri Sendiri. SWA: TOP 250 INDONESIA ORIGINAL BRANDS 2016, pp. 26-39.

Suryadi, D. (2017, Juli 16). Merek-Merek Lokal Disergap Lesu Darah. SWA: TOP 250 INDONESIA ORIGINAL BRANDS 2017, pp. 26-39.

Susanta, Alhabsji, T., Idrus, M., \& Nimran, U. (2013). The Effect of Relationship Quality on Customer Advocacy: The Mediating Role of Loyalty. Journal of Business and Management, 41-52.

Winer, R. (2013). A Framework for Customer Relationship Management. Management Review. USA. Vol.43. No.4, 89-106. 